\title{
АНАЛІЗ ПРАВОВОЇ ПРИРОДИ РЕЧЕЙ ТА ДОКУМЕНТІВ, ДО ЯКИХ ЗАБОРОНЕНО ДОСТУП, У ПОРЯДКУ ЗАСТОСУВАННЯ ТИМЧАСОВОГО ДОСТУПУ ДО РЕЧЕЙ ТА ДОКУМЕНТІВ
}

Маринич Ю. В.

У науковій статті охарактеризовано речі й документи, доступ до яких законодавчо заборонено, та причини їх віднесення до такої категорії. Окрім того, визначено місце таких речей та документів серед елементів адвокатської таємниці, оскільки речі й документи, доступ до яких заборонено, містять інформацію, що становить адвокатську таємницю. Визначено та охарактеризовано способи передачі інформації між захисником та його клієнтом, оскільки аналізована норма КПК України не має однозначності у вказаному питанні.

Ключові слова: тимчасовий доступ до речей та документів, речі й документи доступ до яких заборонено, заходи забезпечення кримінального провадження, кримінальний процес.

В научной статье охарактеризованы вещи и документы, доступ к которым законодательно запрещено, и причины их отнесения к такой категории. Кроме того, определено место таким вещам и документам среди элементов адвокатской тайны. Определены и охарактеризованы способы передачи информации между защитником и его клиентом, поскольку рассматриваемая норма УПК Украины не имеет однозначности в указанном вопросе.

Ключевые слова: временный доступ к вещам и документам, вещи и документы доступ к которым запрещен, меры обеспечения уголовного производства, уголовный процесс.

Marynych Yu. V. Things and documents to which access is prohibited in the procedure of application of temporary access to things and documents

The article describes things and documents, access to which is prohibited in the mode of temporary access to things and documents. It is investigated that Article 161 of the CPC of Ukraine is based on the principle of secrecy of communication and the guarantee of advocacy, according to which it is prohibited to interfere in the personal communication of a lawyer with a client. A number of definitions of lawyer's secrecy were analyzed and it was established that the information contained in the things and documents provided for in Art. 161

(c) Маринич Ю. В., 2020 of the CPC of Ukraine is directly an element of legal secrecy. The article investigates the methods of information transfer between the defender and the client. It is established that the prohibition of temporary access to things and documents contained in Part 1 of Art. 161 of the CPC of Ukraine is due to the fact that correspondence or other forms of information exchange are part of legal secrecy and are protected by relevant sectoral legislation, which provides double protection against interference with such information and its disclosure. Attention is drawn to the fact that we, the legislator in Art. Art. 14, 161 of the CPC of Ukraine, in addition to correspondence, telephone conversations, telegraph and other correspondence, other ways of transmitting information between the defense counsel and the client are indicated, without specifying what applies to them. It is determined that other forms of communication can be understood as all possible ways of transmitting information that are suitable for use and perform their function. In particular, the methods of transmitting information from the client to the defense counsel and vice versa include personal communication, correspondence, transmission of information on the use of means of communication (telephone calls, SMS messages, communication via mobile applications for communication, use of e-mail, etc.). It is proposed to amend Art. 161 of the CPC of Ukraine, supplementing it with the above methods of information transfer.

Key words: temporary access to things and documents, things and documents to which access is forbidden, measures to ensure criminal proceedings, criminal proceedings.

Постановка проблеми та іï актуальність. Тимчасовий доступ до речей та документів, зважаючи на порівняну недавність його створення та введення у вітчизняний кримінальний процес, $\epsilon$ ефективним та часто використовуваним інструментом у системі заходів забезпечення кримінального провадження. Як і більшість заходів забезпечення кримінального провадження, тимчасовий доступ до речей та документів під час його виконання характеризується обмеженням прав та свобод людини. Саме тому правова форма тимчасового доступу до речей та документів 
характеризується обмеженням та забороною в доступі до певної категорії речей та документів. Саме речі та документи, доступ до яких заборонено, $є$ предметом дослідження нашої статті.

Аналіз останніх досліджень і публікацій. Тимчасовий доступ до речей та документів $\epsilon$ предметом досліджень низки науковців, зокрема І. В. Гловюк, Ю.М. Грошевий, О.М. Гумін, О.І. Коровайко, Т.О. Кузубова, О.М. Миколенко, Т.О. Музиченко, М.А. Погорецький, В.В. Рожнова, С.М. Смоков, О.Ю. Татаров, Л.Д. Удалова, B.І. Фаринник, О.Г. Шило.

Метою статті $€$ характеристика речей та документів, доступ до яких заборонено, та причини їх віднесення до такої категорії.

Виклад основного матеріалу. Ст. 161 КПК України встановлено, що речами й документами, до яких заборонено доступ у режимі тимчасового доступу до речей та документів, є листування або інші форми обміну інформацією між захисником та його клієнтом або будь-якою особою, яка представляє його клієнта, у зв'язку з наданням правової допомоги; об'єкти, які додані до такого листування або інших форм обміну інформацією.

Основною метою ст. 161 КПК України $є$ правове обмеження неправомірного доступу до особистого спілкування захисника із клієнтом, що, перш за все, є адвокатською таємницею, а також уникнення порушення права на приватність, що відображається в низці загальноправових та галузевих принципів. В основу норми покладено гарантію адвокатської діяльності, згідно з якою забороняється втручатись в особисте спілкування адвоката із клієнтом (п. 9 ч. 1 ст. 23 ЗУ «Про адвокатуру та адвокатську діяльність») [1], а також принцип таємниці спілкування, передбачений ст. 14 КПК України, яка регламентує, що під час кримінального провадження кожному гарантується таємниця листування, телефонних розмов, телеграфної та іншої кореспонденції, інших форм спілкування.

Принцип таємниці спілкування гарантує право на приватне життя [2, с. 24]. Одним із основних складників цього права $є$ комунікаційний складник (безпека та приватність листування, електронної пошти, телефонних розмов та інших видів приватних комунікацій) [с. 362, 3]. Особисте спілкування $\epsilon$ одним із проявів приватного життя, недоторканності статусу людини, їі комунікування [4, с. 86,].

Право на таємницю листування, телефонних розмов, телеграфної та іншої кореспонденції передбачає заборону будь-кого без згоди особи, яка направляє або одержує листи, спілкується телефоном, через телеграф, факс або за допомогою інших засобів поштового, електричного та електронного зв'язку, знайомитись з іiі листуванням чи іншою кореспонденцією, прослуховувати іï телефонні розмови тощо, а також розголошувати їх зміст або сам факт листування, телефонної розмови, відправлення чи отримання грошового переказу, телеграми та іншої кореспонденції [5].

Указана правова засада $\epsilon$ предметом низки нормативно-правових актів, як вітчизняних, так і міжнародних, згода на ратифікацію яких надана Верховною Радою України. Зокрема, це ст. 8 Конвенції про захист прав людини та основоположних свобод [6], ст. 12 Загальної декларації прав людини [7], ст. 17 Міжнародного пакту про громадянські та політичні права [8].

У національному законодавстві зазначена норма знайшла своє закріплення у ст. 31 Конституції України, де кожному гарантується таємниця листування, телефонних розмов, телеграфної та іншої кореспонденції. Винятки можуть бути встановлені лише судом у випадках, передбачених законом, із метою запобігти злочинові чи з'ясувати істину під час розслідування кримінальної справи, якщо іншими способами отримати інформацію неможливо.

Уточнення принципу таємниці спілкування у кримінальному процесі здійснено в ч. 5 ст. 258 КПК України, яка передбачає заборону втручання у приватне спілкування захисника з підозрюваним, обвинуваченим, засудженим, виправданим.

Продовжуючи аналіз таємниці спілкування та аналізуючи ст. 161 КПК України, ми вбачаємо, що заборона втручання в обмін інформацією передбачена для визначеного кола осіб - ними $\epsilon$ захисник, його клієнт або будь-яка особа, яка представляє його клієнта, у зв'язку з наданням правової допомоги.

Спілкування та взаємодія між захисником та клієнтом має певну специфіку, адже з моменту початку співпраці захисник $є$ довіреною особою клієнта та володіє конфіденційною інформацією. Спілкування адвоката із клієнтом є основою здійснення захисту останнього. Відповідно, дотримання принципу конфіденційності $\epsilon$ необхідною й найважливішою передумовою довірливих відносин між адвокатом та клієнтом, без яких неможливе належне надання правової допомоги, здійснення захисту та представництва. Дія принципу конфіденційності не обмежена в часі [9, с. 65]. 
Інформація, яка стала відома захиснику від його клієнта, автоматично стає предметом адвокатської таємниці, захист якої регулюється ЗУ «Про адвокатуру й адвокатську діяльність». Під час нашого дослідження нам важливо дізнатись, яке місце серед елементів адвокатської таємниці займає спілкування захисника із клієнтом, а також листування та інші форми обміну інформацією між указаними особами.

Адвокатською таємницею $є$ будь-яка інформація, що стала відома адвокату, помічнику адвоката, стажисту адвоката, особі, яка перебуває у трудових відносинах з адвокатом, про клієнта, а також питання, з яких клієнт (особа, якій відмовлено в укладенні договору про надання правової допомоги з передбачених цим Законом підстав) звертався до адвоката, адвокатського бюро, адвокатського об'єднання, зміст порад, консультацій, роз'яснень адвоката, складені ним документи, інформація, що зберігається на електронних носіях, та інші документи й відомості, одержані адвокатом під час здійснення адвокатської діяльності (ч. 1 ст. 22 ЗУ «Про адвокатуру та адвокатську діяльність») [10].

На думку Т.Б. Вільчик, адвокатською таємницею $\epsilon$ будь-яка інформація, зокрема електронна переписка, телефонні та інші розмови адвоката із клієнтом, зокрема через мережу «Інтернет», будь-які документи й відомості, одержані адвокатом під час здійснення адвокатської діяльності [11, с. 350].

P.O. Теліженко систематизував напрацювання вчених про поняття адвокатської таємниці та встановив, що поняття «адвокатська таємниця» визначається як відомості, що отримані адвокатом у зв'язку з наданням юридичної допомоги (А.Л. Ципкін, Ю.І. Стецовський, В.В. Леоненко та Д.П. Ватман), які можуть бути як сприятливими, так і несприятливими для клієнта (Г.Ф. Горський, Л.Д. Кокорєв, Д.П. Котов та Ф.Г. Хайрутдінова), факт звернення та умови, що спонукали до цього, відомості про злочин, його учасників, дані про особисте життя клієнта, відомості з матеріалів справи, листування, матеріали адвокатського досьє (І.Л. Петрухін, М.Ю. Барщевський), умови договору про надання юридичної допомоги (Т.В. Варфоломеєва), суть консультацій, порад та роз'яснень (О.Д. Святоцький, М.М. Михеєнко, О.Г. Яновська), відомості, що можуть завдати шкоди клієнту (Н.В. Черкасова) тощо [12, с. 402].

На переконання С.М. Логінової, адвокатська таємниця - це відомості, які отримані адвокатом у процесі виконання професійних обов'язків, роз- голошення яких може завдати збитків фізичній чи юридичній особі (клієнту). Предметом адвокатської таємниці $є$ факт звернення до адвоката, мотиви, що спонукали до звернення, відмова адвоката від доручення та їі мотиви, умови договору про надання юридичної допомоги, документи, які передані адвокату клієнтом, суть консультацій, порад та роз'яснень, правові документи, що складені адвокатом, відомості, котрі отримані з матеріалів справи, процесуальні дії адвоката, що спрямовані на реалізацію прав клієнта, відомості про особисте життя клієнта та членів його родини, будь-які інші відомості, що можуть бути розголошені лише з дозволу клієнта. [13, с. 10].

Р.М. Луценко ж уважає, що з моменту, коли клієнт переступив поріг юридичної фірми або бюро, все, що там відбулось, є об'єктом адвокатської таємниці [14, с. 26].

На переконання ж І.Ю. Цимбал-Семенчук, адвокатська таємниця охоплює конфіденційність побачень адвоката із клієнтом, конфіденційність адвокатського офісу, конфіденційність листування адвоката із клієнтом [15, с. 66].

Таким чином, проаналізувавши законодавче й авторські визначення адвокатської таємниці, ми доходимо висновку, що спілкування захисника із клієнтом, листування, передання інформації іншим способом $\epsilon$ безпосередньо елементами адвокатської таємниці та співвідносяться з останньою як частина й ціле.

Продовжуючи наше дослідження, ми звертаємо увагу на те, що законодавцем у ст.ст. 14, 161 КПК України, окрім листування, телефонних розмов, телеграфної та іншої кореспонденції, вказані інші способи передачі інформації між захисником та клієнтом, не вказавши, що до них належить. Ми хочемо зупинитись на цьому детальніше, адже таке твердження виглядає досить загальним та вимагає уточнення.

Під час коментування ч. 1 ст. 14 КПК науковцями висловлені такі думки щодо того, що $є$ іншими формами спілкування [16, с. 35]. До інших форм спілкування можна віднести безпосереднє спілкування осіб (не опосередковане технічними чи іншими засобами), спілкування за допомогою телекомунікаційних засобів (електронної пошти, ICQ тощо) [17, с. 66]. Іншими формами спілкування $\epsilon$ повідомлення осіб за допомогою більш сучасних форм зв'язку - телефаксом, пейджинговим зв'язком, електронним тощо [18, с. 61].

Що ж до тлумачення ЄСПЛ, то поняття «кореспонденція» тлумачиться Судом широко й охоплює передачу повідомлень за допомогою таких засобів 
зв'язку, як пошта, телефон, телеграф. Водночас розвиток технологій вимагає більш широкого розуміння поняття «кореспонденція» і включення до нього повідомлень, котрі передаються за допомогою нових засобів зв'язку, наприклад, електронної пошти [с. 42, 19].

Таким чином, ми дійшли висновку, що під іншими формами спілкування можна розуміти всі можливі способи передачі інформації, які придатні для використання та виконують свою функцію. Зокрема, способами передачі інформації від клієнта до захисника й навпаки містять особисте спілкування, листування, передання інформації з використання засобів зв'язку (телефонні дзвінки, смс-повідомлення, спілкування через мобільні додатки для спілкування, використання електронної пошти тощо).

Висновки. Отже, підсумовуючи вищенаведене, ми доходимо висновку, що заборона тимчасового доступу до речей та документів, котрі міститься в ч. 1 ст. 161 КПК України, пов'язана з тим, що листування або інші форми обміну інформацією $€$ частиною адвокатської таємниці та захищаються ЗУ «Про адвокатуру та адвокатську діяльність», що забезпечує подвійний захист від утручання в таку інформацію та їі розкриття.

Іншої думки притримується І.І. Савляк, уважаючи, що заборона тимчасового доступу до речей та документів, передбачених у ч. 1 ст. 161 КПК України, не пов'язана з тим, що заборона втручання у приватне спілкування адвоката із клієнтом є гарантією діяльності адвоката. Автор поділяє думку про те, що ця заборона $є$ уточненням заборони проведення огляду, розголошення, витребування чи вилучення документів, пов' язаних зі здійсненням адвокатської діяльності, що передбачено в п. 4 ч. 1 ст. 23 ЗУ «Про адвокатуру та адвокатську діяльність» [20, с. 125-126,]. Такої ж думки дотримуються й автори Науково-практичного коментаря до Кримінального процесуального кодексу України [21, с. 380].

Однак ми вважаємо, що посягання на спілкування та обмін інформацією між захисником та його клієнтом, обмін інформацією між ними $\epsilon$ зазіханням на адвокатську таємницю, що спричинює відповідні правові наслідки. Ст. 161 КПК України продовжує своєю нормою захист спілкування захисника та клієнта у кримінальному процесі та забезпечує захист від протиправного втручання у відповідне спілкування. У разі відсутності заборони втручання до вищезазначеного спілкування належний захист особи був би неможливим, а убезпечення особи від обвинувачення було 6 мінімізовано.

\section{Література}

1. Про адвокатуру та адвокатську діяльність : Закон України від 05 липня 2012 року № 5076-VI. Верховна Рада України. URL: https://zakon.rada.gov. ua/laws/show/5076-17\#Text (Дата звернення 07.08.2020).

2. Савляк І.І. Таємниця спілкування як засада кримінального провадження : дис. ... канд. юрид. наук : 12.00.09; Нац. акад. внутр. справ. Київ, 2018. 229 с.

3. Шевчук С.Р. Судовий захист прав людини: практика ЄСПЛ у контексті західної правової традиції [2-ге вид., випр., доп.]. Київ : Реферат, 2007. 848с.

4. Науково-практичний коментар до Кримінального процесуального кодексу України від 13 квітня 2012 року /3 за ред. О.А. Банчука, Р.О. Куйбіди, М.І. Хавронюка. Харків, 2013. 1072 с.

5. Петриченко O.I. Боротьба з тероризмом i забезпечення прав людини: чи можливий паритет? URL: http://prava.kiev.ua/pdf/nomer2.pdf.

6. Конвенція про захист прав людини і основоположних свобод: від 11.04.1950 року. Верховна Рада України. URL: https://zakon.rada.gov.ua/laws/ show/995_004 (Дата звернення 25.07.2020).

7. Загальна декларація прав людини: прийнята і проголош. резолюцією 217 А (III) Генеральної Асамблеї ООН від 10 грудня 1948 р. Верховна Рада України. URL: https://zakon.rada.gov.ua/laws/ show/995_015 (Дата звернення 01.08.2020).

8. Міжнародний пакт про громадянські та політичні права від 23 березня 1976 року. Верховна Рада України. URL: https://zakon.rada.gov.ua/laws/ show/995_043 (Дата звернення 01.08.2020).

9. Цимбал-Семенчук І.Ю. Механізм забезпечення адвокатської таємниці. Право і суспільство. 2014. № 5.2. С. 65-69.

10. Про адвокатуру та адвокатську діяльність : Закон України від 05 липня 2012 року № 5076-VI. Верховна Рада України. URL: https://zakon.rada.gov. ua/laws/show/5076-17\#Text (Дата звернення 05.08.2020).

11. Вільчик Т.Б. Адвокатура як інститут реалізації права на правову допомогу: порівняльно-правовий аналіз законодавства країн Європейського Союзу та України : дис. ... д-ра юрид. наук : 12.00.10.

12. Теліженко Р.О. Інформація, що становить адвокатську таємницю. Науковий вісник Львівського державного університету внутрішніх справ. 2011. № 4. С. 401- 408.

13. Логінова С.М. Адвокатська таємниця: теорія і практика : автореф. дис. ... канд. юрид. наук : 12.00.10 ; КНУ ім. Т. Шевченка. Київ, 2002. 19 с.

14. Луценко P.І. Охорона адвокатської таємниці в кримінальному судочинстві, їі об'єкт та суб'єкти. 


\section{досудового слідства}

Правове, нормативне та метрологічне забезпечення системи захисту інформації в Україні. 2009. № 2(19). С. 24-29.

15. Цимбал-Семенчук І.Ю. Механізм забезпечення адвокатської таємниці. Право і суспільство. 2014. № 5.2. С. 65-69.

16. Савляк І.І. Таємниця спілкування як засада кримінального провадження : дис. канд. юрид. наук : 12.00.09; Нац. акад. внутр. справ. Київ, 2018. 229 c.

17. Кримінальний процесуальний кодекс України : Науково-практичний коментар / відп. ред.: С.В. Ківалов, С.М. Міщенко, В.Ю. Захарченко. Харків : Одіссей, 2013. 1104 с.

18. Кримінальний процесуальний кодекс України. Науково-практичний коментар / В.Г. Гончаренко та ін. ; за заг. ред. проф. В.Г. Гончаренка, В.Т. Нора, М.Є. Шумила. Київ, 2012. 1223 с.
19. Практика Європейського суду із прав людини у сфері права громадян на таємницю листування, телефонних розмов, телеграфної та іншої кореспонденції http://vjhr.sk/archive/2018_6/part_2/6.pdf.

20. Савляк I.І. Таємниця спілкування як засада кримінального провадження : дис. канд. юрид. наук : 12.00.09; Нац. акад. внутр. справ. Київ, 2018. 229 c.

21. Кримінальний процесуальний кодекс України : Науково-практичний коментар / відп. ред.: С.В. Ківалов, С.М. Міщенко, В.Ю. Захарченко. Харків, 2013. 1104 с.

Маринич Ю. В., аспірант відділу проблем кримінального права, кримінології та судоустрою Інституту держави і права імені В. М. Корецького Національної академії наук України 